\title{
Science and Christian Faith: The Example of the Turin Shroud
}

\author{
Giulio Fanti* \\ Department of Industrial Engineering, University of Padua, Italy
}

Submission: December 15, 2018; Published: January 17, 2019

*Corresponding author: Giulio Fanti, Department of Industrial Engineering, University of Padua, Via Venezia 1 - 35131Padova, Italy

\section{Summary}

Taking the Turin Shroud as an example, this paper analyzes the strict relationship between science and faith, considered as two forms of knowledge that try to explain the world according to two different methods. In fact, while we are often offered a dualistic vision that tends to separate science and faith, leading them to be two spheres in continuous conflict with each other, the most important Relic of Christianity just shows the opposite.

From the numerous similarities between what is scientifically detected on the Shroud and what is reported in the Holy Scriptures, a clear example of how science and faith can meet together is shown. The Shroud, even furnishing additional scientific details, confirms many facts described in the Bible and vice versa, many clues reported in the Bible have a clearer explanation at the light of the scientific facts shown on Relic.

\section{Introduction}

Science and faith can be considered as two forms of knowledge that try to explain the world according to two different methods. The relationship between scientific knowledge and religious belief has long been the object of reflection by many scholars. Is it possible to find a meeting point between the two spheres? Often we are offered a dualistic vision that separates science and faith, leading them to be two spheres in continuous conflict with each other. Auguste Comte, father of the Positivism, even argues that theology must be outclassed by rational and scientific thought. Science, that has long tried to replace religion [1], promised to respond to the desires of humanity, to resolve all difficulties by thinking to an assurance of happiness on this earth. However, it did not succeed in recreating an earthly paradise and the faith remained, even if feeble.

While many affirm that science and faith must travel on two parallel levels without ever meeting, others, with the author, are convinced that they must meet together to compare and enrich each other, after having traveled mutually independent avenues. In agreement with St. John Paul II "Faith and reason are like two wings on which the human spirit rises to the contemplation of truth" [2]. It is as if a blind man (faith) sustains a lame one (science) which in turn leads the blind (faith) on the path to truth.

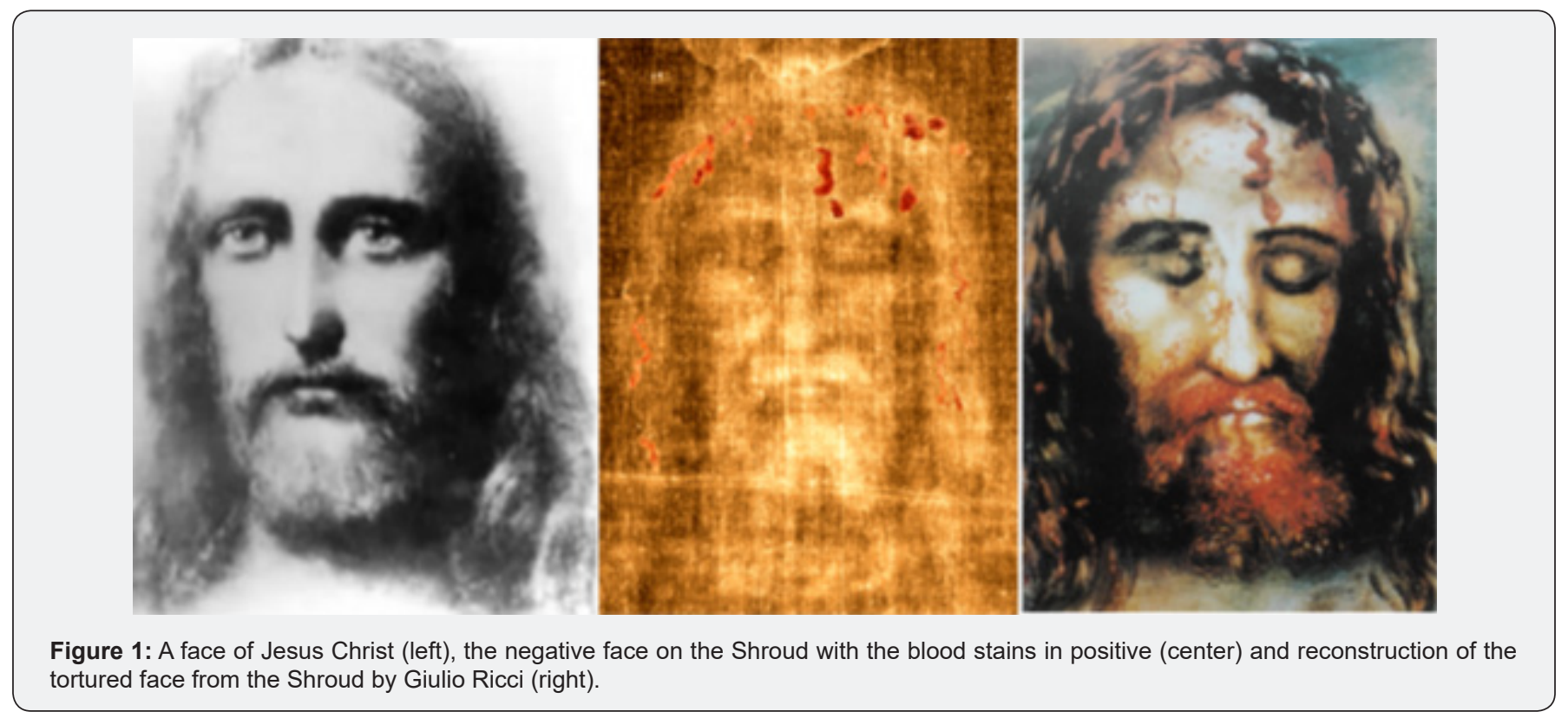

Glob J Arch \& Anthropol 8(1): GJAA.MS.ID.555726 (2019) 
Like in other cases such as the one concerning the explanation of the origin of life where religious texts do not show up in contrast with the results of scientific analyses, the case of the Turin Shroud (or simply Shroud) highlights the close relationship that exists between science and faith. The following presentation shows this strict connection. The Shroud [3-12], see Figure 1 is the archaeological object, as well as religious, more studied in the world. From a scientific point of view, it is important because it shows a double image of a man up to now not reproducible nor explainable; it is also religiously important because, according to the Christian tradition, it shows some traces of the Resurrection of Jesus Christ.

It is an ancient linen cloth, $4.4 \mathrm{~m}$ long and $1.1 \mathrm{~m}$ wide, which wrapped the corpse of a tortured man, scourged, crowned with thorns, crucified and pierced by a spear in the chest. Many are convinced that the Shroud is the sepulchral cloth of Jesus Christ resurrected there after about forty hours from the wrapping. The double body image there impressed has been the subject of intense studies especially during the twentieth century, but even today, it is not technically reproducible and cannot even be explained scientifically. On the Shroud, various signs are visible, more or less important and not easily comprehensible at first glance: the double mirror image of a man, frontal and dorsal, the bloodstains corresponding to the wounds of the Man there wrapped, the stains caused by water, the traces and the holes caused by fires and other minor signs.

Hypothesizing the identification of Jesus Christ with the Man of the Shroud, we analyze here the significant correlations between the scientific aspects detected on the Shroud and what is reported in the Bible, to better understand the close relationship between science and faith [13]. We will see that the quotations from the Bible and in particular from the four Canonic Gospels confirm the observable facts on the Shroud thus evidencing the strict connection between science and faith.

\section{Shroud Results and Corresponding Citations from the Bible}

\section{The asked sign}

The Shroud bears the impressed image of Crist who was put in the tomb and then, according to the Christians, resurrected during the third day. This body image can be interpreted as the sign of Jonah (2,1-11), promised by Jesus, who remained for three days and three nights in the belly of a big fish before being vomited on the ground.

a. no sign shall be given to it except the sign of the prophet Jonah (Mt 16,4).

b. all flesh shall see the salvation of God $(\operatorname{Lk} 3,6)$.

\section{All the human body is Battered}

The Shroud body image shows signs of tortures everywhere. Various injuries, such as that of the side, have not been closed; in fact the casting of post-mortem blood, considered impure by the Jews, was not been touched. It seems that the complete embalming had been postponed to the first day after Saturday because the evening was arriving.

a. From the sole of the foot even to the head there is no soundness in it (Is 1,6).

\section{Many Signs of Tortures on the Head}

The imprint of the face shows numerous swellings: the broken nose, right eye hurt, perhaps blinded by a blow to the scourge, his lower lip cut and various wounds caused by the crown of thorns that are also evident at the nape; actually it does not result a healthy part of the face. It is obviously not easy to identify the sign of a slap or spit on the face of Jesus from the analysis of the Shroud, but the evident and various swellings on the cheeks and on the eyebrows arch, as well as the broken nose, demonstrate that the man was hit and tortured especially in correspondence of the head.

a. The whole head is sick (Is 1,5).

b. They struck His head with a staff and spit on Him (Jn 19.3).

c. and they hit Him with their hands (Mk 15.9).

\section{Flagellation}

It is on the back that is more evident the fury of the torturers; there is in fact a greater concentration of shots. Typically, a man condemned to crucifixion was not punished with additional torture. In the case of the Shroud instead, we may think that the scourging was given as a sentence independent by crucifixion, which was decided later. The author counted on the Shroud at least 372 signs wounds caused by flagellation. Since the sides of the body image are not visible on the Shroud, we may think that the wounds could be about 700 in total. If the Roman flagrum was composed of three cords with two lead balls at each end as someone supposes $[3,6-8]$, we can deduct that the number of blows inflicted was about 120 (since $120 \times 6=720$ ). The area around the heart shows few signs of the scourge because, hitting him, they would have caused the premature death of the condemned.

a. The plowmen plowed upon my back; they made their furrows long." " (Ps 129.3),

b. I gave my back to those who struck me, (Is 50.6).

c. then Pilate took Jesus and flogged Him (Jn 19.1).

\section{Hair and Beard Plucked Out}

On the Shroud the left hair appear longer than the right ones and the right beard seems sparse in some areas. This can be explained as a torture produced by the soldiers.

- "I gave ... my cheeks to those who plucked out my beard; (Is 50:6). 


\section{Coronation of Thorns}

On the Shroud, the presence of a crown of thorns is not clearly visible but forehead, temples and neck have dozens of wounds caused by sharp objects that may be related to a crown of thorns.

a. humiliation has covered my face. (Ps 69.7).

b. The soldiers twisted a crown of thorns and put it on His head (Jn 19.2).

c. and when they wove a crown of thorns, they put it on His head (Mt 27.29).

\section{Transportation of the Cross}

Excoriations imputable to the transport of the cross are evident on the region of the shoulders of the Shroud body image. Jesus repeatedly fell to the ground: this is demonstrated by the dust particles found on the area of the nose and the left knee. As recently highlighted by M. Bevilacqua [11], the cross dislocated his right shoulder during a fall, causing a paralysis of his right arm. The Roman soldiers therefore decided to help Jesus in the transportation of the Cross by forcing a man coming from Cyrene to follow him with the weight of the cross.

a. He went out, carrying His own cross, to a place called The Place of a Skull (Jn 19.17.).

b. they seized Simon of Cyrene, who was coming from the country, and they laid the cross on him to carry it behind Jesus (Lk 23.26).

\section{Crucifixion}

The Shroud shows that Jesus was nailed to the cross with two nails for his hands [14] and one longer for both His feet. The rigor mortis detected on the body image is not consistent with a man lying on a floor, but with a dead man hanged on the cross to which were subsequently repositioned the arms, by breaking the rigor mortis.

a. like a lion they pin my hands and my feet (Ps 22.16).

b. Golgotha. There they crucified Him ... (Jn 19:17-18).

c. and by lawless hands have crucified and killed Him (Acts 2.23).

\section{A Parched Man}

According to various medical analysis [4,6], Jesus died dehydrated, even after significant blood loss caused by the scourging. However, according to several theologians, His thirst was not only physical but also moral because with His voluntary sacrifice aspired to draw to Himself all souls.

a. my throat is parched; (Ps 69.3).

b. in my thirst they gave me vinegar to drink. (Ps 69,21).

\section{A Shout Before Dying}

"The signs of our sins" including the stab to the chest with a spear are impressed there on the Shroud. The wound in the side, following Haemothorax shows the red part of the blood separated by the serous part, transparent like water. It is not yet completely clarified the cause of Jesus' death, but asphyxia, typical of the crucified men, seems to be a contributing cause, not the main reason. If Jesus had died for asphyxia alone, as supposed by someone, it is not easy to explain how he could have issued the loud cry reported in the Gospels. Accentuated by the intense moral pain, along with orthostatic and haemothorax collapse, the haemopericardium diagnosed as a possible cause of death as a result of infarction, produced a violent expansion of the pericardial pleura with consequent shooting retrosternal pain and sudden death associated with a shout.

We must remember that an orthostatic collapse happens when the blood in the body falls down and does not flow to the heart and brain; the hemothorax is a shedding of blood in the pleural cavity after thoracic trauma; the haemopericardium is a shedding of blood in the space between the heart and the pericardial sheet that surrounds him.

a. and Jesus, when He had cried out again with a loud voice, released His spirit (Mt 27, 50).

b. so that they look to $\mathrm{Me}$, whom they have pierced through. (Zechariah 12:10).

c. This is He who came by water and blood-Jesus Christ. He did not come by water only, but by water and blood (1 Jn $5,6)$.

\section{Rigor Mortis and Legs not Broken}

Rigor mortis of Jesus is remarkable on the Shroud [14]; it grew up in a vertical position where the knees were partially bent due to the body collapsing, leaning on the fix point of the nail of the feet. Such a configuration is contrary to the fact that sometimes the bones of the legs were broken to the crucified to hasten death.

On the Shroud some dislocation are evident, but not a fractured bone.
a. nor shall you break a bone of it (Ex 12:46).
b. they did not break His legs (Jn 19,33).
c. For these things happened so that the Scripture should be fulfilled, "Not one of His bones shall be broken (Jn 19,36.).

\section{A Valuable Shroud for the Burial}

According to three of the four canonical Gospels, Jesus was wrapped in a new and valuable sheet, purchased by a wealthy person. The Shroud shows a particularly fine texture and herringbone fabric for an important person, probably a highranking priest. 
a. When Joseph had taken the body, he wrapped it in a clean linen cloth, and laid it in his own new tomb, which he had cut out of the rock (Mt 27.59-60).

\section{A soft bed for the corpse}

The study of the dorsal image of the Shroud shows that the Man was leaned on a soft bed, probably made of spices in dust [8].

a. and You have set me toward the dust of death.(Ps 22,15)

\section{Use of Aromas for the Burial}

P.L. Baima Bollone [15], found traces of aromas such as aloe and myrrh on the Shroud probably used to bury the body of the Man. Interestingly, according to the custom of the Jews, P. Vignon [3] reported that rolled bandages impregnated with aromatic oils surrounded the body wrapped in the Shroud. The term "linen cloths" (from the Greek "othonia"), in the plural, was preferred by the apostle John to the term "sindon" used by the other Evangelists probably because in reference to the set of linens like Shroud, sudarion and various bandages used for burial.

a. Nicodemus, ... also came, bringing a mixture of myrrh and aloes, weighing about seventy-five pounds (Jn 19:39).

b. Then they took the body of Jesus and wrapped it in linen cloths with the spices, as is the burial custom of the Jews (Jn 19:40).

\section{Spillage of Separated Blood from the Chest Due to Lance Shot}

It is evident from the Shroud the escaping of separate blood (plasma and post mortem serum) due to the side stubbed by a spear after death. On the right side of the chest, according to P. Barbet [4], there is a wound whose margins widened and well defined typical, of a blow inflicted after death. Among the contributory causes of death, we must not forget the moral pain of Jesus seeing Him treated in that way, just from people who had come to save. The insult has therefore accentuated the effects of orthostatic collapse also followed by the hemothorax.

a. because for Your sake I have endured insult; (Ps 69.8).

b. my heart is like wax; it is melted inside my body. (Ps 22:14).

c. Insults have broken my heart, and I am sick; (Ps 69,20).

d. However, one of the soldiers pierced His side with a spear and immediately blood and water came out (Jn 19:34).

\section{Absence of Sign of Corruption}

The evident rigor mortis of the corpse and the lack of spots on the body image, produced by emissions of putrefaction gases also in correspondence of the orifices (e.g. nose and mouth), demonstrate that the body of Jesus did not see any kind of corruption [14]. According to the Bible in fact Jesus' life was therefore not abandoned in the hell because on the third day
Jesus rose from the dead. The lack of smearing in correspondence of the Shroud bloodstains, conserved in a humid environment like the sepulcher, demonstrate that the corpse was not moved after wrapping. Therefore, we must think that Jesus was not placed in the niche carved into the rock, but he was left on the stone for the preparation of the corpse, waiting for the finish of embalming operations to be performed after the Holy Saturday.

a. For You will not leave my soul in Sheol, nor will You suffer Your godly one to see corruption. (Ps 16:10).

b. For You will not abandon my soul to Hades, nor will You allow Your Holy One to see corruption. (Acts 2:27).

\section{A Burst of Energy for the body Image Formation?}

According to many scholars [1,6,8-10], the body image imprinted on the Shroud, not yet scientifically explainable, was probably formed by a brief and intense burst of energy, maybe even of electric type [16], which could be related to a lightning. If we refer to the hypothesis of the disappearance of the corpse due to the concurrent radiation that formed the body image, the Shroud presents a double sign: the death of Jesus and the burn caused by the intense energy source that produced the body image.

a. And you shall let nothing of it remain until the morning, but that of it which remains until the morning you shall burn with fire.... 11 It is the Lord's Passover. (Exodus 12:10).

b. For as the lightning comes from the east and flashes to the west, so will be the coming of the Son of Man ( $t$ 24,27).

c. For as the lightning flashes and lights up the heavens from one side to the other, so will the Son of Man be in His day (Lk 17,24).

\section{Resurrection}

Science cannot study the Resurrection as a scientific fact because it is not reproducible, but we can formulate scientific hypothesis based on this phenomenon to try to explain what can be scientifically detected on the Shroud.

From the Shroud it results what follows:

a. The Man remained there wrapped for not more the about forty hours because there are no signs of putrefaction, therefore someway the corpse went out of the linen Sheet.

b. To explain the body image of the Shroud it seems necessary the hypothesis of a burst of energy coming from the corpse $[8,9]$, but a dead man only exchanges relatively small quantities of thermal energy with the environment.

c. The absence of smearing in all the stains visible on the Shroud due to the blood re-dissolved by fibrinolysis in the humid environment of the sepulcher, implies that no skinfabric movements happened during wrapping.

d. It is not possible for the moment to scientifically explain how Jesus came out from the Shroud, but when science stops, 
all other hypotheses can be considered, Resurrection not excluded. Supported by various experimental data J. Jackson [9] supposes that Jesus became mechanically transparent with respect to the sagging Sheet and produced a flash of energy, which would be the cause of image formation.

e. Some scholars with the author think that the body image could have been originated by an intense electric field, which produced the so-called corona discharge, directly responsible for the image [16]. While some scholars tend to form hypotheses related to an earthquake, the author thinks that this supernatural energy can be directly related to the Resurrection.

f. This description from the Evangelists makes us think about what happened for the Shroud when the body image formed.

g. The Transfiguration of Mount Tabor is a prelude to the Resurrection of Jesus, He "was transfigured before them. His face shone as the sun, and His garments became white as the light" (Mt 17,2).

h. The Resurrection of Jesus .... (Lk 24).

i. He foresaw this and spoke concerning the resurrection of the Christ." (Acts 2:31).

j. And then there was a great earthquake. For the angel of the Lord descended from heaven and came and rolled back the stone from the door and sat on it (Mt 28,2).

k. Paul wrote this letter in the years 53-55 AD, in a period when there were certainly too many eyewitnesses and this could not be an invention without historical foundation. Then He was seen by over five hundred brothers at once, of whom the greater part remain to this present time, though some have passed away (1.Cor 15.6).

Paul wrote this letter in the years 53-55 AD, in a period when there were certainly too many eyewitnesses and this could not be an invention without historical foundation.

\section{The Position of the Shroud that Pushed John to See and Believe}

The synthetic description of the sepulchral linens made by the apostle John is not exhaustive, but we can think that the very particular position of both the Shroud and the Sudarium helped a lot him to believe in the Resurrection, that was a preannounced fact but not understood up to this moment. Probably the particular shape of the Shroud lowered on the sepulchral bed and the Sudarium that was hardened by the aromas, placed in a form that seemed to wrap the lacking head, led the apostle John to believe in the Resurrection of Christ.

a. ${ }^{3}$ So Peter came out with the other disciple and they went toward the tomb. ${ }^{4}$ They both ran together, and the other disciple outran Peter and came to the tomb first. ${ }^{5}$ Stooping down and looking in, he saw the linen cloths lying. Yet he did not enter. ${ }^{6}$ Then Simon Peter came, following him, and went inside the tomb. He saw the linen cloths lying there, ${ }^{7}$ and the cloth that was around His head, not lying with the linen cloths, but wrapped in a place by itself. ${ }^{8}$ Then the other disciple, who came first to the tomb, went in also. He saw and believed. ${ }^{9}$ For as yet they did not know the Scripture, that $\mathrm{He}$ must rise from the dead."(Jn 20.3 to 9).

First of all we must observe the description of "the cloth that was around His head, not lying with the linen cloths, but wrapped in a place by itself." And we may interpret this cloth as the sudarium that was posed on Jesus' head, not laying with the Shroud, but still wrapping up the disappeared head. This significant description deserves an additional comment from

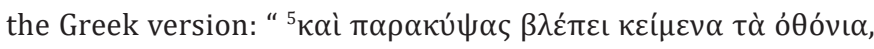

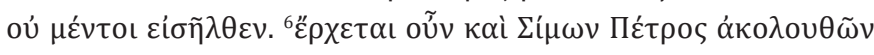

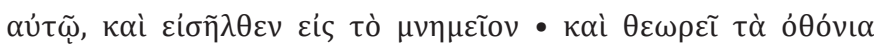

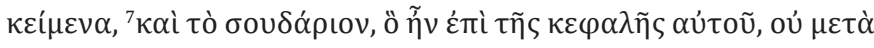

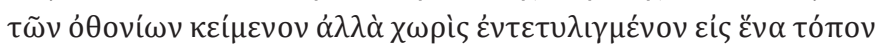

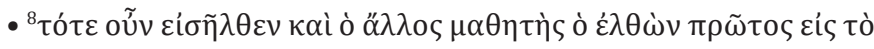

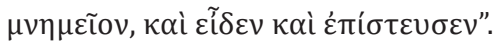

This text reports three different instants, characterized by three different verbs used to describe the facts when the two Apostles saw the Shroud in the sepulcher. These verbs similar but different, $\beta \lambda \varepsilon \dot{\varepsilon} \pi \varepsilon \iota, \theta \varepsilon \omega \rho \varepsilon \tilde{\imath}, \varepsilon \tilde{\varepsilon} \delta \varepsilon v$ have the same main meaning -to see-, but they are used to characterize different peculiar situations:

a. $\quad \beta \lambda \varepsilon \dot{\pi} \pi \varepsilon \mathrm{l}$, referred to the Apostle Peter, means -to see- in the sense of -turning his eyes- with a touch of attention but with a limited use of one of the five senses;

b. $\theta \varepsilon \omega \rho \varepsilon \tilde{\imath}$, referred to the apostle John, instead indicates -to see- in a way that contemplates something beyond, in deeper way, involving thought and reflection; it means trying to understand an hidden meaning and it derives from the same root $\theta \varepsilon \omega \rho$ of theory and theorem;

c. $\varepsilon \tilde{\varepsilon} \delta \varepsilon v$, again referred to John, indicates -to see- in a different way, meaning to be careful, but also experiencing and showing that John deeply meditated on this fact.

It seems clear now that John, after his deep meditation ( $\varepsilon \tilde{\delta} \delta \varepsilon v$ ) on the particular disposition of both the Shroud and the sudarium, still wrapping the lacking head, was pushed

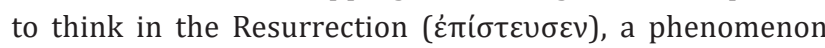
that was preannounced to him by the same Jesus, but that was very difficult for him to understand without the physical signs seen in the sepulcher.

\section{Studying the Shroud}

Waiting to contemplate the face of Jesus after the Resurrection from the dead, we can now contemplate His image observing the Holy Shroud.

a. When You said, "Seek My face," my heart said to You, "Your face, Lord, I will seek" (Ps 27:8). 


\section{Global Journal of Archaeology \& Anthropology}

It is instead not forget the text of Isaiah who even mention a sheet or a shroud in prophecy that could have a direct connection with the Shroud.

b. (the Lord) will destroy in this mountain the covering (translated as "shroud" too in other versions) which is over all peoples, even the veil that is spread over all nations (Is 25.7).

\section{Results from the Bible Contrary to the Shroud}

The author is not able to find citations of the Bible and, in particular, from the four Canonic Gospels against either the scientific facts detectable on the Shroud or the Relic itself but he will try to answer to possible questions raised by the readers of this paper. Only two points offered by some persons against the existence of the Shroud are here discussed.

\section{The Shroud body image is not mentioned in the Gospels}

Some state that the body image of the Shroud is not authentic because, if true, the Gospels would have certainly mentioned it. This fact is true, but according to the author, it is in favor of the Shroud authenticity too. In fact, experimental tests with coronal discharge [16] demonstrated that only a latent image could be formed by using this source of electric energy. The latent image "develops" with time and a source of heating at about $200{ }^{\circ} \mathrm{C}$ is necessary to produce a visible image in few minutes. It is therefore easy to think that months or better years were necessary for the Shroud to form its body image and this is why the Gospels did not mention it: the Apostles probably did not see any visible image on the Shroud, but only the bloodstains that were surely not so important to be mentioned in their Gospel.

\section{The Gospel of John speaks of bandages but not of a Shroud}

Unfortunately the Greek language, from which derives the translations of the Gospels, is not rich of terms and therefore a single word has various meanings. While the other Apostles (Mt 27,59 Mc 15,46 Lc 23,53) who were not present to the burial mention the word "Sindon", that is Shroud, to make reference to the most important Object used in the sepulcher, John uses the generic term "Othonia" that may be translated as "linens" or "bandages". Some translator of the Gospel selected this last term for his unhappy translation, thus inducing the reader to think to a wrapping like that used for the Egyptian mummies. In this case instead it seems more proper the first term "linens", because John, who was present during the burial, wanted to mention not only the Shroud, but also other pieces of linen used there, like the sudarium and the rolls of bandages full of spices posed at the sides of the corpse to better conserve it. Therefore nothing seems strange if John used a term not directly referred to the Shroud but to all the linen fabrics used that Friday evening.

\section{Concluding Remarks}

From the numerous similarities detected between the Shroud and the Holy Scriptures, we see that there is here a full agreement between science and faith. In agreement with prof. Eberhard Lindner who widely studied the Shroud, we can therefore think that the most important Relic of Christianity is a "Scientific Gospel". In fact it scientifically confirms many facts described in the Bible, representing them all together concentrated in one sheet and even adding new details. Therefore the Shroud summarizes the facts of the Passion described in the Gospels and, while confirming their historical veracity, in turn these facts confirm the authenticity of the Relic too. For example, in the Gospels we read: "Then Pilate took Jesus and flogged Him " (Jn 19.1-2). The reader of our times has probably some difficulties to imagine what was the severity of punishment inflicted on Jesus about 2000 years ago because flogging is a kind of torture nowadays almost forgotten. On the Shroud however, by analyzing the hundreds wounds left by the blows of the scourge, it is scientifically documented the harsh punishment and it is easier for us to understand what physical suffering were inflicted to that Man. Therefore, we can say with M. Laconi that the Shroud meets our materialist expectations, in fact, while the New Testament puts the blood of Jesus in front of the heart, warmed by faith, the Shroud instead puts it in front of our eyes.

\section{Acknowledgement}

The author thanks Wanda René Thompson of Ichthus Inspirational Publications (ichthushouse.org) for the translation from Italian of some sentences, Dr. John Donahue of Shroud Science Group on Yahoo for his advices and Dr. Susan Lara, Managing Editor of Juniper Publishers with her collaborators for the help and kindness manifested during the publication of both the present paper and the two already published:

-Fanti G. "Why is the Turin Shroud Authentic?". Glob J Arch \& Anthropol. 2018; 7(2): 555707, https://juniperpublishers.com/ gjaa/pdf/GJAA.MS.ID.555707.pdf

-Fanti G. "Why is the Turin Shroud Not Fake?". Short Communication, Glob J Arch \& Anthropol. 2018: 7(3), https:// juniperpublishers.com/gjaa/pdf/GJAA.MS.ID.555715.pdf

\section{References}

1. Leroy JC (2015) Il Sudario di Cahors, Cantagalli Siena Italy.

2. St. John Paul II, Fides et Ratio (1998) To the Bishops of the Catholic Church on the Relationship between Faith and Reason.

3. Vignon p (1902) Le Linceul du Christ, (Masson edn), Italy.

4. Barbet PA (1963) Doctor at Calvary: the passion of our Lord Jesus Christ as described by a surgeon. The Earl of Wicklow (trans), Garden City, Image Books edn, New York, USA.

5. Schwalbe LA, Rogers RN (1982) Physics and chemistry of the Shroud of Turin, a summary of the 1978 investigation. Analytica Chimica Acta 135: 3-49.

6. Antonacci M (2016) Test the Shroud: At the Atomic and Molecular Levels, Forefront Publishing Company, ( $1^{\text {st }}$ edn), USA.

7. Faccini (2008) The death of the Shroud Man: an improved review. Int Conf. on the Shroud, Columbus Ohio, USA.

8. Fanti G, Malfi P (2015) The Shroud of Turin - First century After Christ! Pan Stanford Publishing Pte. Ltd., Singapore. 
9. Jackson JP (1990) Is the image on the Shroud due to a process heretofore unknown to modern science? Shroud Spectrum International 34: 3-29.

10. Jackson JP (2017) The Shroud of Turin: A Critical Summary of Observations, Data and Hypotheses.

11. Bevilacqua M, Fanti G, D’Arienzo M, Porzionato A, Macchi V, et al. (2014) How was crucified the Man of the Turin Shroud? Injury 45: 142-148.

12. Wilson I, Miller V (1986) The Mysterious Shroud. Doubleday Image Book, USA.

13. Linzey JF, Holy Bible (2014) The Modern English Version (MEV).
14. Bevilacqua M (2018) Rigor Mortis and News obtained by the Body's Scientific Reconstruction of the Turin Shroud Man.

15. Baima Bollone PL (1983) La presenza della mirra, dell'aloe e del sangue sulla Sindone", in: "La Sindone, Scienza e Fede", Atti del Il Convegno Nazionale di Sindonologia, Bologna 1981, CLUEB, Bologna, pp. 169-174.

16. Fanti G (2010) Can Corona Discharge explain the body image formation of the Turin Shroud? J Imaging Sci Technol 54(2): 020508.

\section{Your next submission with Juniper Publishers} will reach you the below assets

- Quality Editorial service

- Swift Peer Review

- Reprints availability

- E-prints Service

- Manuscript Podcast for convenient understanding

- Global attainment for your research

- Manuscript accessibility in different formats

( Pdf, E-pub, Full Text, Audio)

- Unceasing customer service

Track the below URL for one-step submission https://juniperpublishers.com/online-submission.php 